\title{
Correlation of compaction characteristics of standard and reduced Proctor tests
}

Shaivan Hirebelaguly Shivaprakash BE

Graduate Research Assistant, School of Civil and Environmental Engineering, Georgia Institute of Technology, Atlanta, GA, USA (corresponding author: shaivan.hs@gatech.edu)
Asuri Sridharan PhD

Senior Research Scientist, Fellow of the Indian National Science Academy, New Delhi, India; Formerly Professor of Civil Engineering, Indian Institute of Science, Bangalore, India

Analysis of reduced Proctor test and standard Proctor test results collected from literature indicates that it is possible to replace standard Proctor with reduced Proctor due to the advantages that the reduced Proctor test requires $40 \%$ less compaction energy, requires no modifications to the standard Proctor compaction apparatus unlike other small compaction tests, and the soil particle size requirements remain the same as those for the standard Proctor test. Correlations were also developed for compaction characteristics obtained by the modified Proctor test and the reduced Proctor test in order to estimate compaction characteristics at the modified Proctor energy level by just performing the reduced Proctor test. The optimum moisture content was found to correlate well with liquid limit. In addition, for the reduced Proctor test, maximum dry density was found to have a very good correlation with optimum moisture content.

\section{Notation}

$G_{\mathrm{s}} \quad$ specific gravity of soil

$I_{\mathrm{P}} \quad$ plasticity index of soil

$w_{\mathrm{L}} \quad$ liquid limit of soil

$w_{\mathrm{P}} \quad$ plastic limit of soil

\section{Introduction}

The standard Proctor test is the most widely used laboratory test to determine the compaction characteristics of soils (i.e. the maximum dry density (MDD) and optimum moisture content (OMC)). As per ASTM D 698 (ASTM, 2012), the standard Proctor test is carried out in a mould of diameter 4 inches $(101.6 \mathrm{~mm})$ and height 4.58 inches $(116.4 \mathrm{~mm})$, with the soil being compacted in three layers and each layer of soil receiving 25 blows of a $2.5 \mathrm{~kg}$ rammer falling freely from a height of 12 inches $(304.8 \mathrm{~mm})$. The reduced Proctor test, also known as the 15-blow compaction test, is carried out in the same manner as the standard Proctor test except that each layer of soil being compacted receives 15 blows instead of 25 . The compaction characteristics of soils are essential in practical applications of mechanical compaction for ground improvement, such as in the construction of earth and earth-retaining structures, highway and railway embankments, airfield pavements, clay landfill liners and so on. By determining the MDD of soil in a laboratory, it is possible to compact the soil in the field to the required density by maintaining the moisture content at nearly optimum. Furthermore, laboratory samples can be prepared at the same density and moisture content as those likely to be attained after compaction in the field. These samples can then be tested for the determination of other geotechnical engineering properties such as shear strength, compressibility and permeability, which serve as the basis for the initial design of an embankment, earth dam or clay landfill liner. Thus, laboratory compaction tests provide the basis for $(a)$ determining the percentage compaction and optimum water content needed to achieve the required engineering properties and $(b)$ controlling construction to ensure that the required compaction and water contents are achieved.
Mechanical compaction, being cost-effective compared to other soil stabilisation techniques for ground improvement, is frequently employed in construction practice where the structure is entirely or partly made up of soils. Compaction of soil results in an increase in its density and shear strength, and a reduction in settlement and permeability. However, to achieve the desired improvement in the engineering properties of soil in field, it is important that the compaction characteristics of the soil be determined first. Hence, for a large-scale project, performing laboratory compaction tests on several different soil samples becomes necessary, which requires a large amount of soil, time and compaction effort. Any attempt to reduce the amount of soil, time or compaction effort needed for performing a laboratory compaction test would thus be most welcome. In this regard, the reduced Proctor test - which requires less time and 40\% less effort in terms of compaction energy - was examined as a possible replacement for the standard Proctor test.

\section{Background information}

The standard Proctor test requires a large amount of soil and considerable time and compaction effort to obtain the complete compaction curve for a given soil. For any highway or earthworks project, a large number of compaction tests may need to be carried out to determine the compaction characteristics of soils taken from different borrow pits with different physical properties. Many attempts have been made in the past to predict the compaction curve and the compaction characteristics of soils. Joslin (1959) developed 26 bulk density-moisture content curves along with penetration resistance curves, also known as Ohio's typical moisture-density curves, based on 10149 compaction test results. Out of these 26 curves, an appropriate compaction curve could be chosen for a given soil by comparing the maximum bulk density and OMC values from the curves with those obtained from one-point moisturedensity and penetration resistance tests performed in the laboratory. With a similar objective, Horpibulsuk et al. (2009) developed 26 modified Ohio's curves for each of the four 
energy levels - namely, half-standard, standard, half-modified and modified Proctor energies. These curves can be used for a rapid estimation of laboratory compaction curves from a single set of data of dry unit weight and water content. Many studies correlating the index properties of soils (i.e. liquid limit (LL) and plastic limit (PL)) with compaction characteristics are available in the literature. Ramiah et al. (1970) used the LL to correlate with both MDD and OMC. Blotz et al. (1998) used the LL to obtain coefficients used for the estimation of compaction characteristics. Al-Khafaji (1993) used both the LL and the PL to correlate with the OMC. On the contrary, Gurtug and Sridharan (2004), Sridharan and Nagaraj (2005) and Sivrikaya et al. (2008) showed that the OMC correlates well with the PL but not with the LL. Recently, Nagaraj et al. (2015) reported that the modified PL predicts MDD and OMC better than the PL. Statistical regression models were used in the aforementioned studies to develop the correlations between the compaction characteristics and index properties of soil. However, Najjar et al. (1996), Basheer (2001), Gunaydin (2009) and Isik and Ozden (2013) used artificial neural networks (ANNs) for the prediction of compaction characteristics and reported that the ANN models performed better than statistical regression models.

The US Army Corps of Engineers engineering manual on laboratory soils testing (US ACE, 1970) states that the '15-blow compaction test', also known as the reduced Proctor test, shall be used for lower compaction effort. In the reduced Proctor test, preparation of the soil sample, the compaction procedure and the requirements of the mould and rammer are the same as those of the standard Proctor test except that each layer of soil being compacted receives 15 blows instead of 25 . The compaction energy of the standard Proctor is $594.5 \mathrm{~kJ} / \mathrm{m}^{3}$ whereas that of the reduced Proctor is $40 \%$ lower $\left(356.7 \mathrm{~kJ} / \mathrm{m}^{3}\right)$. Daniel and Benson (1990) stated that the reduced Proctor corresponds to a reasonable minimum level of compaction energy for a typical soil liner or cover. They used modified Proctor, standard Proctor and reduced Proctor tests to represent a broad range of compaction effort likely to be encountered in the field for the construction of compacted soil liners. Daniel and $\mathrm{Wu}$ (1993), Benson and Trast (1995), Abichou et al. (2000) and Osinubi and Nwaiwu (2005) used the reduced Proctor test to identify the acceptable range of water content-density criteria, satisfying the minimum hydraulic conductivity requirements of the soil liner over a broad range of compaction energies, for the construction of compacted soil liners.

The reduced Proctor test requires no new apparatus or modification to the existing standard Proctor test apparatus, and the particle size criteria as recommended for the standard Proctor test hold good. Furthermore, soil sample preparation and the compaction procedure are the same as those for the standard Proctor test. The reduced Proctor test can thus be performed in any soil mechanics laboratory with a standard Proctor compaction apparatus. Therefore, if the compaction characteristics obtained from reduced Proctor are nearly the same as those obtained from standard Proctor, then the reduced Proctor test could very well replace the standard Proctor test. The results of reduced Proctor tests and standard Proctor tests were collected from the literature and examined to ascertain if the reduced Proctor test could be a suitable replacement for the standard Proctor test.

\section{Methodology}

Data were collected on reduced Proctor, standard Proctor and modified Proctor test, along with LL and PL values, for 61 soils from 16 sources (Abichou et al., 2000; Benson and Trast, 1995; Benson et al., 1999; Blotz et al., 1998; Daniel and Benson, 1990; Daniel and Wu, 1993; Horz, 1983; Kim and Daniel, 1992; Miller et al., 2002; Nagaraj et al., 2006; Osinubi and Bello, 2011; Osinubi and Nwaiwu, 2005; Phifer et al., 1994; Sharma et al., 2019; Taha and Kabir, 2005; White et al., 2005). The data are presented in Table 1. From the data collected, the soil properties varied over a wide range: the LL ranged from $16 \%$ to $83 \%$, the PL ranged from $8 \%$ to $35 \%$, the clay content ranged from $16 \%$ to $65 \%$ and the fines content ranged from $10.2 \%$ to $94 \%$. Out of the 61 soils, fines content data was available for 42 soils. Based on this data for 42 soils, 31 soils were fine-grained and 11 soils were coarse-grained. For the remaining 19 soils, grain size distribution data were not provided, so it could not be determined if the soils were coarse-grained or fine-grained.

Among the 16 sources, Osinubi and Nwaiwu (2005), Osinubi and Bello (2011) and Taha and Kabir (2005) performed the compaction tests according to the British standard BS 1377-4 (BSI, 1990), while Sharma et al. (2019) followed the Indian standard IS 2720-7 (BIS, 1980) for performing compaction tests. In these four studies, the method of determination of the LL (either by the Casagrande cup or falling cone) was not stated. In the remaining 12 studies, the compaction tests were performed according to the ASTM standard D698 (ASTM, 2012) and the LL of the soil was determined by the Casagrande cup test as per the ASTM standard.

With these data, compaction characteristics obtained from RPTs and SPTs were compared. In addition, correlations were developed for OMC with LL, PL and plasticity index for both reduced Proctor and standard Proctor test results. Correlations between MDD and OMC were also determined.

\section{Results and discussion}

Figure 1 shows the relationship between the maximum dry unit weight from the reduced Proctor $\left(\mathrm{MDD}_{\mathrm{RP}}\right)$ and the maximum dry unit weight from the standard Proctor $\left(\mathrm{MDD}_{\mathrm{SP}}\right)$. The equation is

\section{1. $\mathrm{MDD}_{\mathrm{RP}}=0.98 \mathrm{MDD}_{\mathrm{SP}}-0.31$}

with a very high coefficient of determination $\left(R^{2}=0.94\right)$. 
Table 1. Index properties and compaction tests results for 61 soils obtained from literature

\begin{tabular}{|c|c|c|c|c|c|c|c|c|c|c|c|c|c|c|c|c|c|}
\hline \multirow[b]{2}{*}{ Test } & \multirow[b]{2}{*}{$G_{\mathrm{s}}$} & \multirow[b]{2}{*}{$\begin{array}{c}\text { Gravel: } \\
\quad \%\end{array}$} & \multirow[b]{2}{*}{$\begin{array}{c}\text { Sand: } \\
\%\end{array}$} & \multirow[b]{2}{*}{$\begin{array}{c}\text { Silt: } \\
\%\end{array}$} & \multirow[b]{2}{*}{$\begin{array}{c}\text { Clay: } \\
\%\end{array}$} & \multirow[b]{2}{*}{$\begin{array}{c}\text { Fines: } \\
\%\end{array}$} & \multirow[b]{2}{*}{$\begin{array}{r}\text { LL: } \\
\%\end{array}$} & \multirow[b]{2}{*}{$\begin{array}{r}\text { PL: } \\
\%\end{array}$} & \multirow[b]{2}{*}{$\begin{array}{l}I_{\mathrm{p}}: \\
\%\end{array}$} & \multicolumn{2}{|c|}{$\begin{array}{l}\text { Modified } \\
\text { Proctor test }\end{array}$} & \multicolumn{2}{|c|}{$\begin{array}{l}\text { Standard } \\
\text { Proctor test }\end{array}$} & \multicolumn{2}{|c|}{$\begin{array}{l}\text { Reduced } \\
\text { Proctor test }\end{array}$} & \multirow[b]{2}{*}{$\begin{array}{c}\text { Degree of } \\
\text { saturation: \% }\end{array}$} & \multirow[b]{2}{*}{ Reference } \\
\hline & & & & & & & & & & $\begin{array}{l}\text { MDD: } \\
\mathrm{kN} / \mathrm{m}^{3}\end{array}$ & $\begin{array}{c}\text { OMC: } \\
\%\end{array}$ & $\begin{array}{l}\text { MDD: } \\
\mathrm{kN} / \mathrm{m}^{3}\end{array}$ & $\begin{array}{c}\text { OMC: } \\
\%\end{array}$ & $\begin{array}{l}\text { MDD: } \\
k N / m^{3}\end{array}$ & $\begin{array}{c}\text { OMC: } \\
\%\end{array}$ & & \\
\hline 1 & - & - & - & - & - & - & 56 & 19 & 37 & 18.20 & 13.90 & 15.50 & 23.20 & 14.66 & 25.80 & 89.74 & Horz (1983) \\
\hline 2 & - & - & - & - & - & - & 41 & 19 & 22 & 18.37 & 14.20 & 16.67 & 18.90 & 16.25 & 20.80 & 88.39 & Horz (1983) \\
\hline 3 & - & - & - & - & - & - & 30 & 21 & 9 & 17.96 & 14.70 & 16.81 & 17.50 & 16.53 & 19.00 & 83.78 & Horz (1983) \\
\hline 4 & - & - & - & - & - & - & 55 & 28 & 27 & 15.80 & 23.50 & 14.40 & 29.40 & 14.10 & 30.60 & 95.85 & Daniel and Benson (1990) \\
\hline 5 & - & - & - & - & - & - & 34 & 16 & 18 & 18.80 & 13.10 & 17.30 & 17.50 & 16.80 & 19.40 & 90.90 & Daniel and Benson (1990) \\
\hline 6 & - & 3 & 9 & 40 & 48 & 88 & 36 & 17 & 19 & 19.84 & 12.07 & 18.22 & 14.95 & 17.69 & 16.74 & 91.27 & Kim and Daniel (1992) \\
\hline 7 & - & - & - & - & - & - & 30 & 18 & 12 & 19.00 & 12.00 & 18.40 & 14.00 & 17.60 & 16.00 & 88.26 & Daniel and Wu (1993) \\
\hline 8 & - & - & - & - & - & - & 75 & 29.9 & 45.1 & 14.91 & 26.30 & 13.44 & 31.60 & 12.95 & 34.60 & 88.92 & Phifer et al. (1994) \\
\hline 9 & 2.80 & 0 & 6 & 29 & 65 & 94 & 70 & 32 & 38 & 17.10 & 19.00 & 15.40 & 24.00 & 13.80 & 27.50 & 85.75 & Benson and Trast (1995) \\
\hline 10 & 2.70 & 0 & 6 & 54 & 40 & 94 & 49 & 23 & 26 & 19.40 & 12.50 & 17.60 & 18.00 & 17.00 & 21.00 & 96.25 & Benson and Trast (1995) \\
\hline 11 & 2.75 & 2 & 24 & 48 & 28 & 76 & 27 & 12 & 15 & 20.50 & 8.00 & 19.10 & 12.50 & 18.50 & 14.00 & 83.35 & Benson and Trast (1995) \\
\hline 12 & 2.80 & 3 & 8 & 48 & 41 & 89 & 35 & 16 & 19 & 19.40 & 13.60 & 17.40 & 18.10 & 17.00 & 18.20 & 87.59 & Benson and Trast (1995) \\
\hline 13 & 2.90 & 0 & 12 & 25 & 63 & 88 & 53 & 12 & 41 & 19.00 & 12.00 & 17.90 & 16.00 & 16.60 & 19.00 & 78.73 & Benson and Trast (1995) \\
\hline 14 & 2.80 & 0 & 6 & 41 & 53 & 94 & 67 & 21 & 46 & 18.40 & 16.00 & 16.30 & 21.50 & 15.60 & 23.00 & 87.86 & Benson and Trast (1995) \\
\hline 15 & 2.68 & 0 & 48 & 36 & 16 & 52 & 29 & 13 & 16 & 20.40 & 10.00 & 19.00 & 12.00 & 18.50 & 13.00 & 83.81 & Benson and Trast (1995) \\
\hline 16 & 2.78 & 0 & 19 & 56 & 25 & 81 & 37 & 17 & 20 & 19.50 & 12.00 & 17.50 & 14.00 & 16.70 & 15.00 & 69.70 & Benson and Trast (1995) \\
\hline 17 & 2.80 & 7 & 8 & 48 & 37 & 85 & 33 & 14 & 19 & 19.30 & 12.60 & 17.70 & 16.50 & 17.10 & 17.10 & 83.72 & Benson and Trast (1995) \\
\hline 18 & 2.80 & 8 & 18 & 48 & 26 & 74 & 31 & 13 & 18 & 19.70 & 11.80 & 17.70 & 15.09 & 17.20 & 17.80 & 76.56 & Benson and Trast (1995) \\
\hline 19 & 2.80 & 3 & 35 & 42 & 20 & 62 & 24 & 13 & 11 & 21.20 & 9.00 & 20.40 & 10.00 & 18.70 & 13.50 & 80.81 & Benson and Trast (1995) \\
\hline 20 & 2.78 & 2 & 9 & 58 & 31 & 89 & 43 & 17 & 26 & 18.60 & 14.00 & 16.50 & 20.00 & 16.00 & 21.00 & 85.17 & Benson and Trast (1995) \\
\hline 21 & 2.80 & 1 & 14 & 41 & 44 & 85 & 32 & 18 & 14 & 20.60 & 10.00 & 19.50 & 13.00 & 18.30 & 14.00 & 89.08 & Benson and Trast (1995) \\
\hline 22 & - & - & - & - & - & - & 33 & 14 & 19 & 19.30 & 12.20 & 17.70 & 17.50 & 17.10 & 18.50 & 97.38 & Blotz et al. (1998) \\
\hline 23 & - & - & - & - & - & - & 31 & 13 & 18 & 19.40 & 12.50 & 17.80 & 16.50 & 17.20 & 18.50 & 93.44 & Blotz et al. (1998) \\
\hline 24 & - & - & - & - & - & - & 35 & 16 & 19 & 19.40 & 11.50 & 17.50 & 16.60 & 17.00 & 18.50 & 89.23 & Blotz et al. (1998) \\
\hline 25 & - & - & - & - & - & - & 27 & 17 & 10 & 20.50 & 9.00 & 19.10 & 13.00 & 18.60 & 14.40 & 93.47 & Blotz et al. (1998) \\
\hline 26 & - & - & - & - & - & - & 41 & 8 & 33 & 18.70 & 13.30 & 16.70 & 18.00 & 16.20 & 20.00 & 84.55 & Blotz et al. (1998) \\
\hline 27 & - & - & - & - & - & - & 17 & 14 & 3 & 21.70 & 7.90 & 20.40 & 9.40 & 19.80 & 10.10 & 88.39 & Blotz et al. (1998) \\
\hline 28 & - & - & - & - & - & - & 18 & 11 & 7 & 22.00 & 7.30 & 20.50 & 8.90 & 19.90 & 9.30 & 85.57 & Blotz et al. (1998) \\
\hline 29 & - & - & - & - & - & - & 55 & 24 & 31 & 17.70 & 16.00 & 15.70 & 23.00 & 15.20 & 26.00 & 91.89 & Blotz et al. (1998) \\
\hline 30 & - & - & - & - & - & - & 32 & 17 & 15 & 19.50 & 10.90 & 18.00 & 15.20 & 17.50 & 15.80 & 89.17 & Blotz et al. (1998) \\
\hline
\end{tabular}




\begin{tabular}{|c|c|c|c|c|c|c|c|c|c|c|c|c|c|c|c|c|c|}
\hline \multirow[b]{2}{*}{ Test } & \multirow[b]{2}{*}{$G_{s}$} & \multirow[b]{2}{*}{$\begin{array}{c}\text { Gravel: } \\
\quad \%\end{array}$} & \multirow[b]{2}{*}{$\begin{array}{c}\text { Sand: } \\
\quad \%\end{array}$} & \multirow[b]{2}{*}{$\begin{array}{l}\text { Silt: } \\
\%\end{array}$} & \multirow[b]{2}{*}{$\begin{array}{l}\text { Clay: } \\
\%\end{array}$} & \multirow[b]{2}{*}{$\begin{array}{c}\text { Fines: } \\
\quad \%\end{array}$} & \multirow[b]{2}{*}{$\begin{array}{l}\text { LL: } \\
\%\end{array}$} & \multirow[b]{2}{*}{$\begin{array}{r}\text { PL: } \\
\%\end{array}$} & \multirow[b]{2}{*}{$\begin{array}{l}I_{\mathrm{p}}: \\
\%\end{array}$} & \multicolumn{2}{|c|}{$\begin{array}{l}\text { Modified } \\
\text { Proctor test }\end{array}$} & \multicolumn{2}{|c|}{$\begin{array}{l}\text { Standard } \\
\text { Proctor test }\end{array}$} & \multicolumn{2}{|c|}{$\begin{array}{l}\text { Reduced } \\
\text { Proctor test }\end{array}$} & \multirow[b]{2}{*}{$\begin{array}{c}\text { Degree of } \\
\text { saturation: \% }\end{array}$} & \multirow[b]{2}{*}{ Reference } \\
\hline & & & & & & & & & & $\begin{array}{l}\mathrm{MDD}: \\
\mathrm{kN} / \mathrm{m}^{3}\end{array}$ & $\begin{array}{l}\text { OMC: } \\
\%\end{array}$ & $\begin{array}{l}\text { MDD: } \\
\mathrm{kN} / \mathrm{m}^{3}\end{array}$ & $\begin{array}{c}\text { OMC: } \\
\%\end{array}$ & $\begin{array}{l}\text { MDD: } \\
\mathrm{kN} / \mathrm{m}^{3}\end{array}$ & $\begin{array}{l}\text { OMC: } \\
\%\end{array}$ & & \\
\hline 31 & - & - & - & 48 & 37 & 85 & 33 & 14 & 19 & 19.30 & 12.20 & 17.70 & 17.50 & 17.10 & 18.50 & 97.38 & Benson et al. (1999) \\
\hline 32 & - & - & - & 48 & 26 & 74 & 31 & 13 & 18 & 19.50 & 12.10 & 17.70 & 16.70 & 16.80 & 18.90 & 92.93 & Benson et al. (1999) \\
\hline 33 & - & - & - & 48 & 41 & 89 & 35 & 16 & 19 & 19.40 & 11.50 & 17.50 & 16.60 & 17.00 & 18.50 & 89.23 & Benson et al. (1999) \\
\hline 34 & - & - & - & 48 & 28 & 76 & 27 & 17 & 10 & 20.50 & 9.00 & 19.10 & 13.00 & 18.60 & 14.40 & 93.47 & Benson et al. (1999) \\
\hline 35 & - & - & - & - & - & 86 & 41 & 18 & 23 & 18.70 & 13.30 & 16.70 & 18.00 & 16.20 & 20.00 & 84.55 & Benson et al. (1999) \\
\hline 36 & - & - & - & - & - & 86 & 42 & 20 & 22 & 18.70 & 13.30 & 16.70 & 18.00 & 16.20 & 20.00 & 84.55 & Benson et al. (1999) \\
\hline 37 & - & - & - & - & - & 86 & 40 & 18 & 22 & 18.70 & 13.30 & 16.70 & 18.00 & 16.20 & 20.00 & 84.55 & Benson et al. (1999) \\
\hline 38 & 2.54 & - & - & - & - & 12.7 & 21 & 18 & 3 & 18.72 & 11.10 & 17.89 & 10.25 & 16.48 & 15.40 & 66.28 & Abichou et al. (2000) \\
\hline 39 & 2.52 & - & - & - & - & 11.3 & 20 & 18 & 2 & 19.27 & 11.60 & 18.19 & 13.00 & 16.92 & 16.10 & 91.24 & Abichou et al. (2000) \\
\hline 40 & 2.56 & - & - & - & - & 12.1 & 27 & 19 & 8 & 18.68 & 9.70 & 17.30 & 12.20 & 16.71 & 16.20 & 69.15 & Abichou et al. (2000) \\
\hline 41 & 2.54 & - & - & - & - & 12.4 & 23 & 18 & 5 & 19.28 & 9.40 & 18.24 & 11.60 & 16.82 & 14.70 & 80.48 & Abichou et al. (2000) \\
\hline 42 & 2.61 & - & - & - & - & 10.2 & 20 & 17 & 3 & 18.50 & 10.80 & 17.90 & 12.70 & 16.57 & 16.10 & 77.02 & Abichou et al. (2000) \\
\hline 43 & 2.58 & - & - & - & - & 16.4 & 23 & 17 & 6 & 19.02 & 10.00 & 18.18 & 11.50 & 16.78 & 15.30 & 75.65 & Abichou et al. (2000) \\
\hline 44 & 2.54 & - & - & - & - & 13.2 & 21 & 18 & 3 & 19.32 & 9.80 & 18.27 & 11.00 & 16.85 & 14.80 & 76.79 & Abichou et al. (2000) \\
\hline 45 & 2.51 & - & - & - & - & 15 & 29 & 22 & 7 & - & - & 16.20 & 15.50 & 14.40 & 13.50 & 74.83 & Abichou et al. (2000) \\
\hline 46 & 2.51 & - & - & - & - & 14 & 27 & 20 & 7 & - & - & 16.90 & 15.00 & 16.00 & 15.00 & 82.39 & Abichou et al. (2000) \\
\hline 47 & - & - & 56 & 27 & 17 & 44 & 16 & 9 & 7 & 21.70 & 6.40 & 20.00 & 9.00 & 19.70 & 10.80 & 77.61 & Miller et al. (2002) \\
\hline 48 & - & - & 3 & 38 & 59 & 97 & 40 & 23 & 17 & 17.60 & 19.20 & 15.80 & 24.20 & 15.20 & 25.60 & 98.23 & Miller et al. (2002) \\
\hline 49 & - & - & 2 & 34 & 64 & 98 & 83 & 23 & 60 & 16.70 & 22.50 & 14.70 & 29.10 & 13.40 & 34.20 & 99.38 & Miller et al. (2002) \\
\hline 50 & 2.67 & 0.5 & 33 & 32 & 34 & 66 & 41 & 23 & 18 & 18.45 & 14.00 & 16.70 & 18.80 & 16.17 & 20.80 & 88.31 & Osinubi and Nwaiwu (2005) \\
\hline 51 & 2.68 & 1 & 28 & 38 & 34 & 72 & 40 & 23 & 17 & 18.75 & 12.50 & 16.88 & 16.80 & 16.38 & 18.80 & 80.76 & Osinubi and Nwaiwu (2005) \\
\hline 52 & 2.69 & 2 & 34 & 35 & 29 & 64 & 43 & 26 & 17 & 18.14 & 13.30 & 16.30 & 18.00 & 15.74 & 19.30 & 78.23 & Osinubi and Nwaiwu (2005) \\
\hline 53 & - & - & 35 & 20 & 45 & 65 & 68 & 35 & 33 & 16.36 & 20.70 & 14.47 & 26.20 & 13.93 & 27.10 & 86.35 & Taha and Kabir (2005) \\
\hline 54 & - & - & - & - & - & - & 29 & 12 & 17 & - & - & 18.83 & 11.98 & 18.33 & 13.58 & 81.81 & White et al. (2005) \\
\hline 55 & - & - & - & - & - & - & 33 & 19 & 14 & 19.07 & 11.78 & 17.37 & 16.04 & 16.94 & 17.37 & 84.29 & Nagaraj et al. (2006) \\
\hline 56 & 2.66 & - & - & - & 23.63 & 63.55 & 43 & 29 & 14 & 18.84 & 13.80 & 18.05 & 14.40 & 17.56 & 14.90 & 85.95 & Osinubi and Bello (2011) \\
\hline 57 & 2.62 & - & - & - & 21.57 & 59.2 & 48 & 32 & 16 & 18.64 & 14.00 & 18.05 & 14.50 & 17.46 & 15.00 & 89.62 & Osinubi and Bello (2011) \\
\hline 58 & 2.65 & - & - & - & 25.39 & 66.4 & 44 & 28 & 16 & 17.85 & 13.50 & 17.17 & 14.20 & 16.38 & 14.50 & 73.17 & Osinubi and Bello (2011) \\
\hline 59 & 2.72 & - & 19.73 & - & - & 80.27 & 48.81 & 18.28 & 30.53 & 17.55 & 17.79 & 16.45 & 18.33 & 16.15 & 18.53 & 80.12 & Sharma et al. (2019) \\
\hline 60 & 2.69 & - & 66.8 & - & - & 33.2 & 23.45 & 15.38 & 8.07 & 19.63 & 11.90 & 18.93 & 13.23 & 18.32 & 13.59 & 90.32 & Sharma et al. (2019) \\
\hline 61 & - & - & - & - & - & - & - & - & - & 20.38 & 9.52 & 19.03 & 11.78 & 18.44 & 12.53 & 83.61 & Sharma et al. (2019) \\
\hline
\end{tabular}




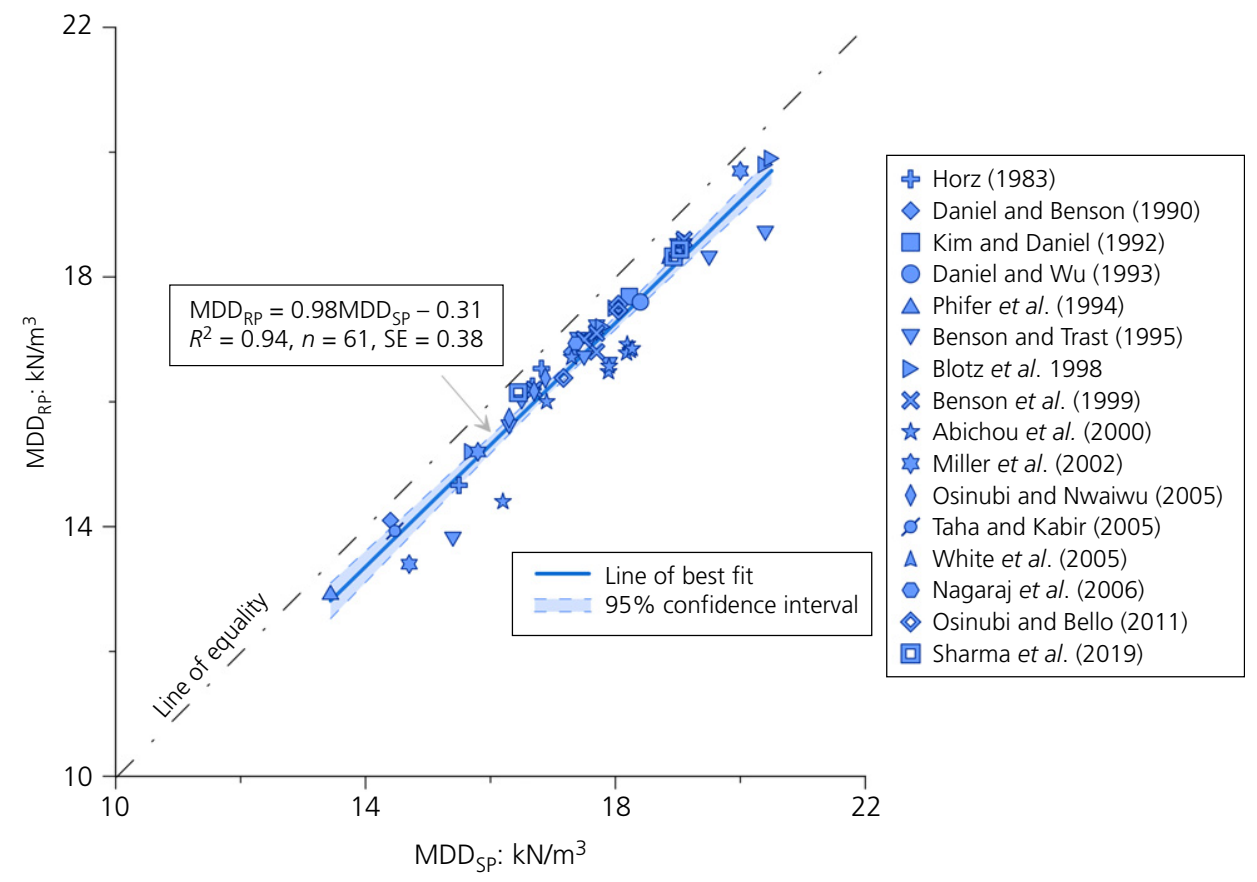

Figure 1. Relationship between maximum dry unit weight from reduced Proctor $\left(\mathrm{MDD}_{\mathrm{RP}}\right)$ and maximum dry unit weight from standard Proctor tests $\left(\mathrm{MDD}_{\mathrm{SP}}\right)$

All the data points lie just below the line of equality, as the MDD of the reduced Proctor is slightly less than that of the standard Proctor. The reason for this may be that the reduced compaction energy of the reduced Proctor test leads to lower density values. However, most of the data points are very close to the line of equality. In fact, if some of the scattered points below the statistical average line were to be removed, then the statistical average line would shift very close to the line of equality. Hence, even though the MDD from the reduced Proctor is slightly less than that of the standard Proctor, the reduced Proctor test could be a possible replacement for the standard Proctor test because it requires $40 \%$ less compaction energy and no further changes are required to the compaction mould or specification of the soil sample.

Figure 2 shows the relationships of maximum dry unit weight obtained from modified Proctor ( $\mathrm{MDD}_{\mathrm{MP}}$ ), standard Proctor and reduced Proctor tests. These are given by

2. $\mathrm{MDD}_{\mathrm{MP}}=0.85 \mathrm{MDD}_{\mathrm{SP}}+4.05, \quad R^{2}=0.9$

3. $\mathrm{MDD}_{\mathrm{MP}}=0.86 \mathrm{MDD}_{\mathrm{RP}}+4.54, \quad R^{2}=0.9$

It can be observed that MDD obtained from standard Proctor correlates well with MDD from modified Proctor. Similarly, MDD from reduced Proctor bears a very good correlation with
MDD from modified Proctor. Using Equations 2 and 3, it is possible to predict the MDD at the modified Proctor energy level if the MDD at either the standard Proctor or reduced Proctor energy level is known. Hence, the modified Proctor test - which requires a large amount of soil, more time and 4.5 times the compaction energy of the standard Proctor test - can be avoided.

Figure 3 shows the relationship between OMC obtained from reduced Proctor and standard Proctor test. It is given by

4. $\mathrm{OMC}_{\mathrm{RP}}=1.02 \mathrm{OMC}_{\mathrm{SP}}+1.41$

with a very high coefficient of determination $\left(R^{2}=0.94\right)$.

The relationship between $\mathrm{OMC}_{\mathrm{RP}}$ and $\mathrm{OMC}_{\mathrm{SP}}$ also shows a very good correlation, similar to the case of the MDD. Similar to Figure 1, most of the data points are close to the line of equality. Thus, from Figures 1 and 3, it can be concluded that since both the MDD and OMC values obtained from reduced Proctor are very close to those from standard Proctor, the reduced Proctor test can replace the standard Proctor test.

Figure 4 shows the relationships between OMC obtained from modified Proctor $\left(\mathrm{OMC}_{\mathrm{MP}}\right)$, standard Proctor and reduced Proctor. These equations are

5. $\mathrm{OMC}_{\mathrm{MP}}=0.72 \mathrm{OMC} \mathrm{SP}+1.02, \quad R^{2}=0.88$ 


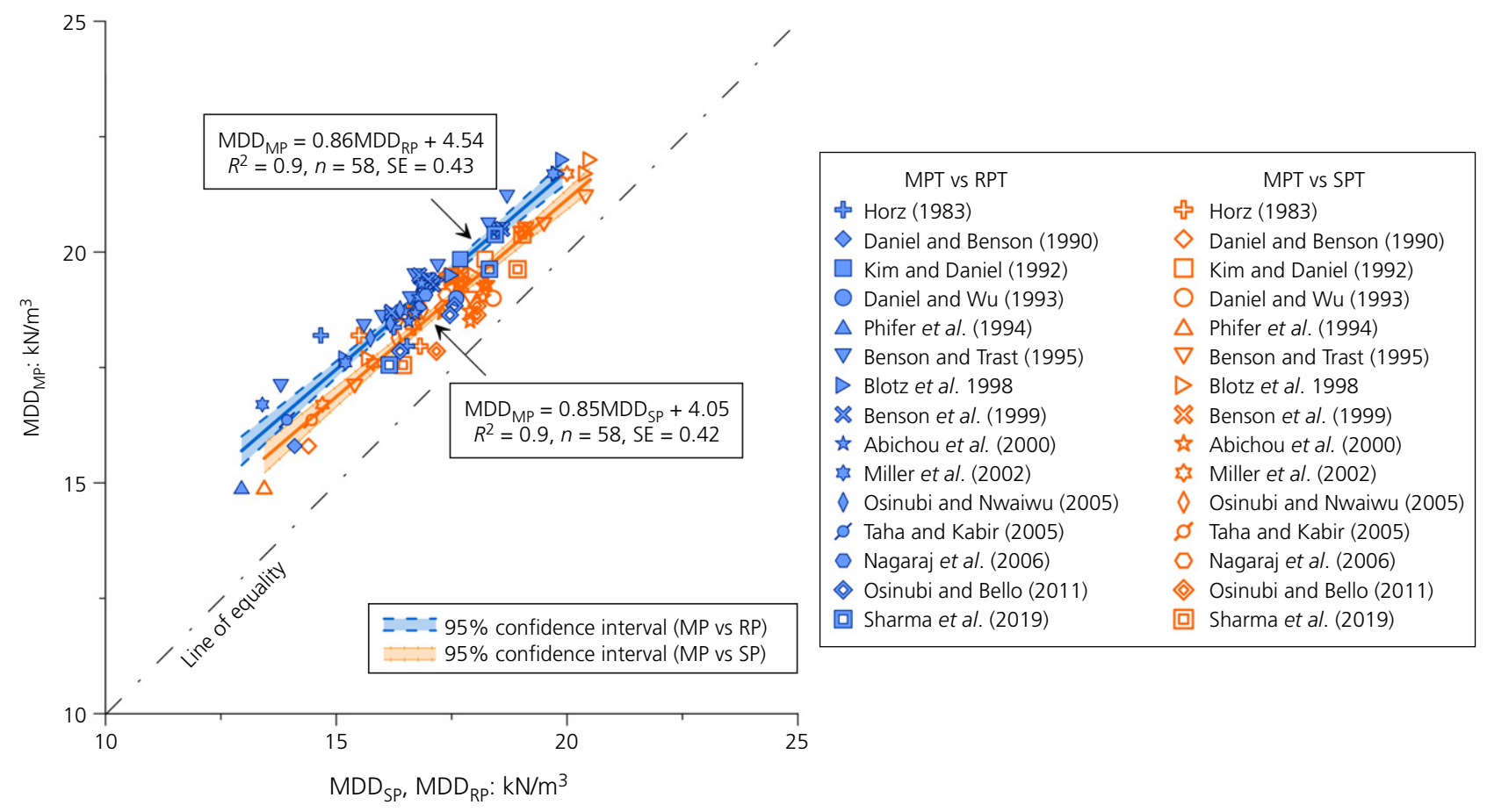

Figure 2. Relationships between maximum dry unit weight from modified Proctor (MDD $\mathrm{MP}$ ) and maximum dry unit weight from standard Proctor $\left(\mathrm{MDD}_{\mathrm{SP}}\right)$ and reduced Proctor tests $\left(\mathrm{MDD}_{\mathrm{RP}}\right)$

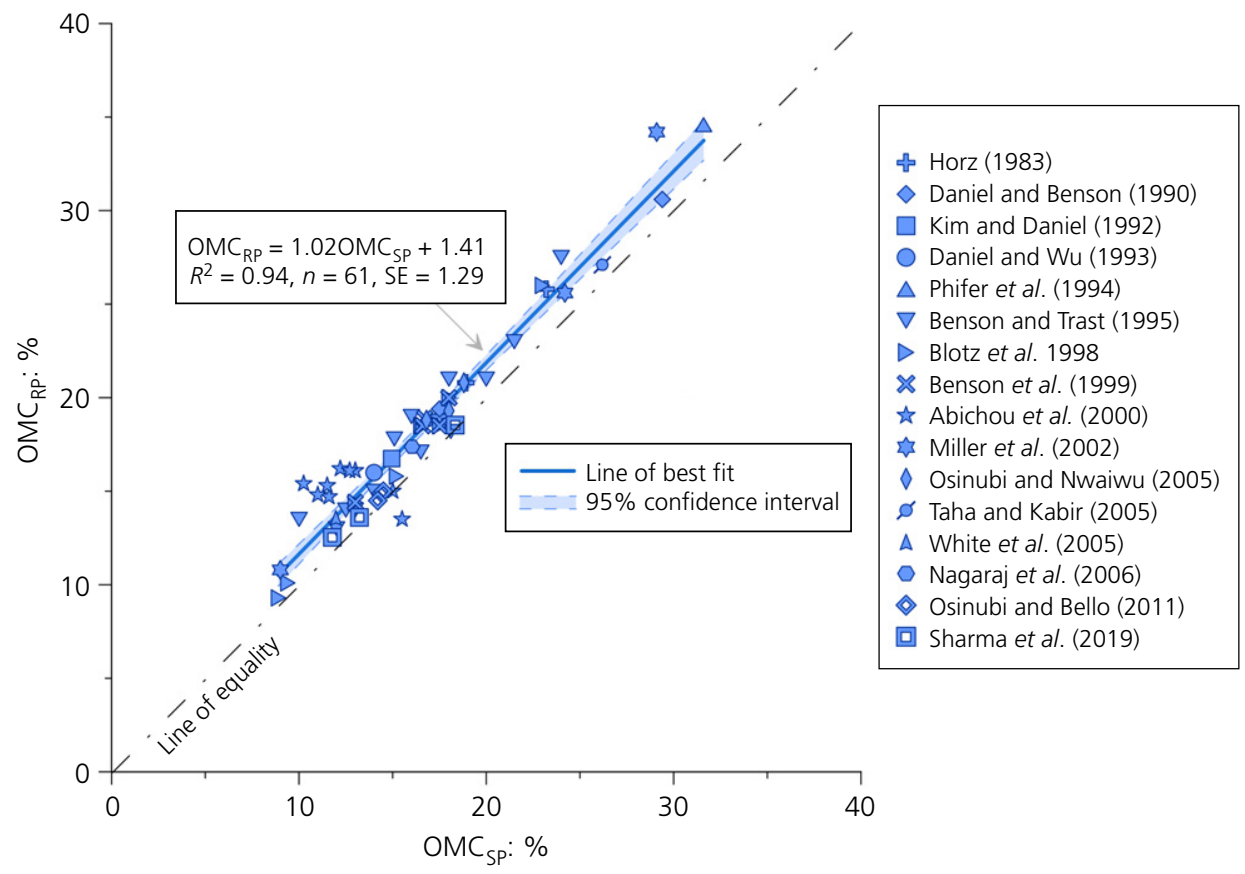

Figure 3. Relationship between $\mathrm{OMC}$ from reduced Proctor $\left(\mathrm{OMC}_{\mathrm{RP}}\right)$ and $\mathrm{OMC}$ from standard Proctor tests $\left(\mathrm{OM} \mathrm{C}_{\mathrm{SP}}\right)$

6. $\mathrm{OMC}_{\mathrm{MP}}=0.67 \mathrm{OMC} \mathrm{RP}+0.55, \quad R^{2}=0.84$

There is thus a good correlation between OMC obtained from modified Proctor and OMC from standard Proctor and reduced Proctor. Using Equations 2, 3, 5 and 6, it is possible to predict both the MDD and OMC at the modified Proctor energy level if the compaction characteristics at either the standard Proctor or reduced Proctor energy level are known. 


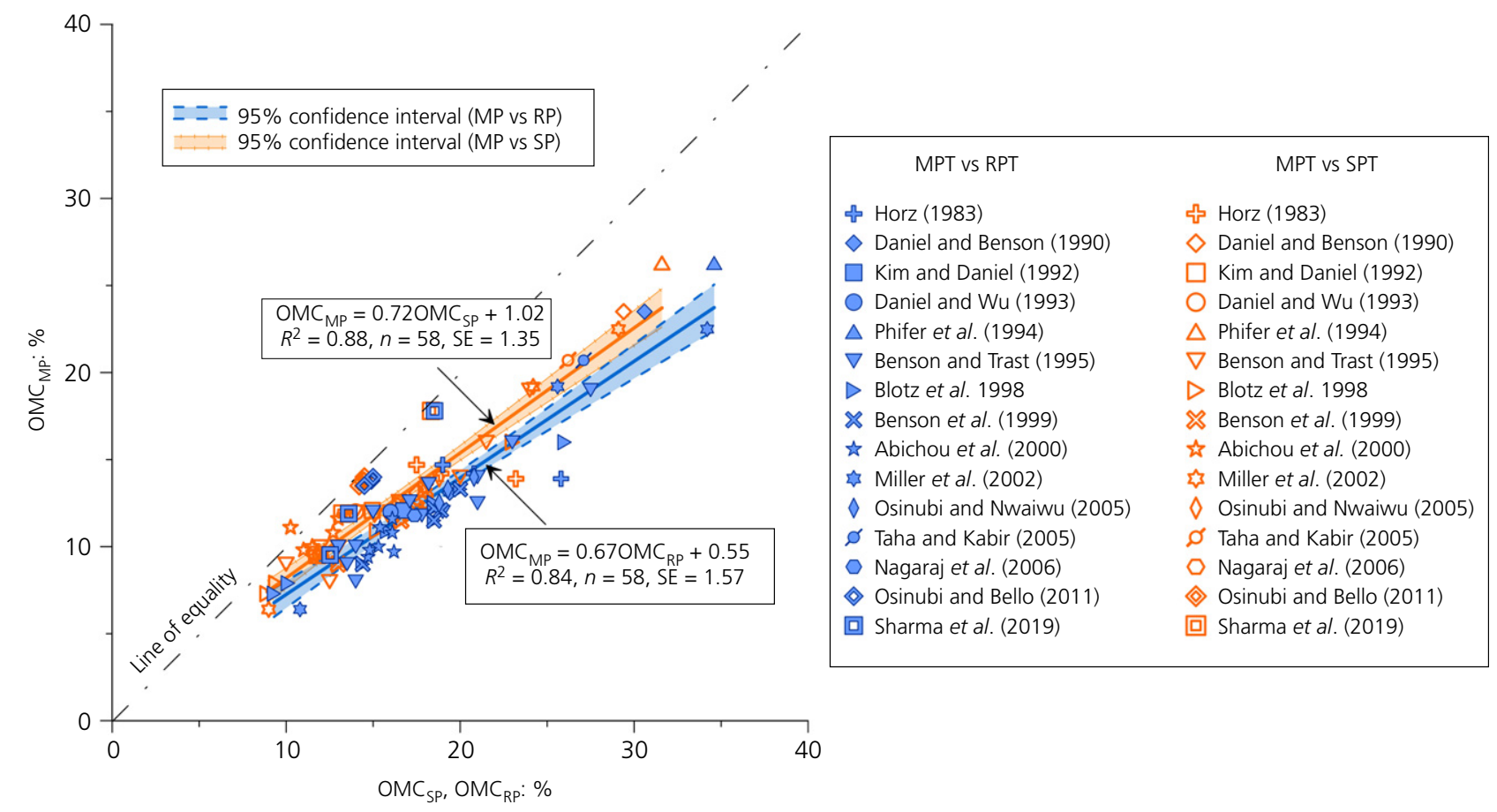

Figure 4. Relationships between $\mathrm{OMC}$ from modified Proctor $\left(\mathrm{OMC} \mathrm{MP}_{\mathrm{MP}}\right)$ and $\mathrm{OMC}$ from standard Proctor $\left(\mathrm{OMC} \mathrm{SP}_{\mathrm{P}}\right)$ and reduced Proctor test $\left(O M C_{R P}\right)$

It is thus possible to obtain the compaction characteristics at the modified Proctor energy level by just performing the reduced Proctor test, which requires less soil, time and compaction effort than that needed for the modified Proctor test.

Figure 5 shows the relationship between OMC obtained from reduced Proctor and LL $\left(w_{\mathrm{L}}\right)$, given by

7. $\mathrm{OMC}_{\mathrm{RP}}=0.31 w_{\mathrm{L}}+6.85$

with a coefficient of determination of $R^{2}=0.75$. A correlation was also developed between OMC from standard Proctor with LL.

\section{8. $\mathrm{OMC}_{\mathrm{SP}}=0.3 w_{\mathrm{L}}+5.48$}

with a coefficient of determination of $R^{2}=0.77$.

Both Equations 7 and 8 have good coefficients of determination. Hence, the OMC can be estimated from the LL, since LL tests are invariably carried out in any soil investigation.

Correlations were also developed for OMC obtained from reduced Proctor and standard Proctor with PL $\left(w_{\mathrm{P}}\right)$. These are given by

9. $\mathrm{OMC}_{\mathrm{RP}}=0.49 w_{\mathrm{P}}+9.21$ with a low coefficient of determination $\left(R^{2}=0.3\right)$ and

10. $\mathrm{OMC}_{\mathrm{SP}}=0.49 w_{\mathrm{P}}+7.31$

with a low coefficient of determination $\left(R^{2}=0.33\right)$.

Both Equations 9 and 10 for the relationship between OMC and PL have lower coefficients of determination than the OMC-LL equations. This result contradicts some results in the literature that PL correlates with OMC better than LL (Gurtug and Sridharan, 2004; Sivrikaya et al., 2008; Sridharan and Nagaraj, 2005). However, based on the results from this study, it would be better to use LL to predict OMC rather than PL.

Figure 6 shows the relationship between the OMC obtained from reduced Proctor and the plasticity index $\left(I_{\mathrm{P}}\right)$. The relation between OMC obtained from standard Proctor and plasticity index was also determined. These are given by

11. $\mathrm{OMC}_{\mathrm{RP}}=0.36 I_{\mathrm{P}}+11.7, \quad R^{2}=0.65$

12. $\mathrm{OMC}_{\mathrm{SP}}=0.34 I_{\mathrm{P}}+10.25, \quad R^{2}=0.65$

Equations 11 and 12 for the variation of OMC with plasticity index have lower $R^{2}$ values than the correlations for 


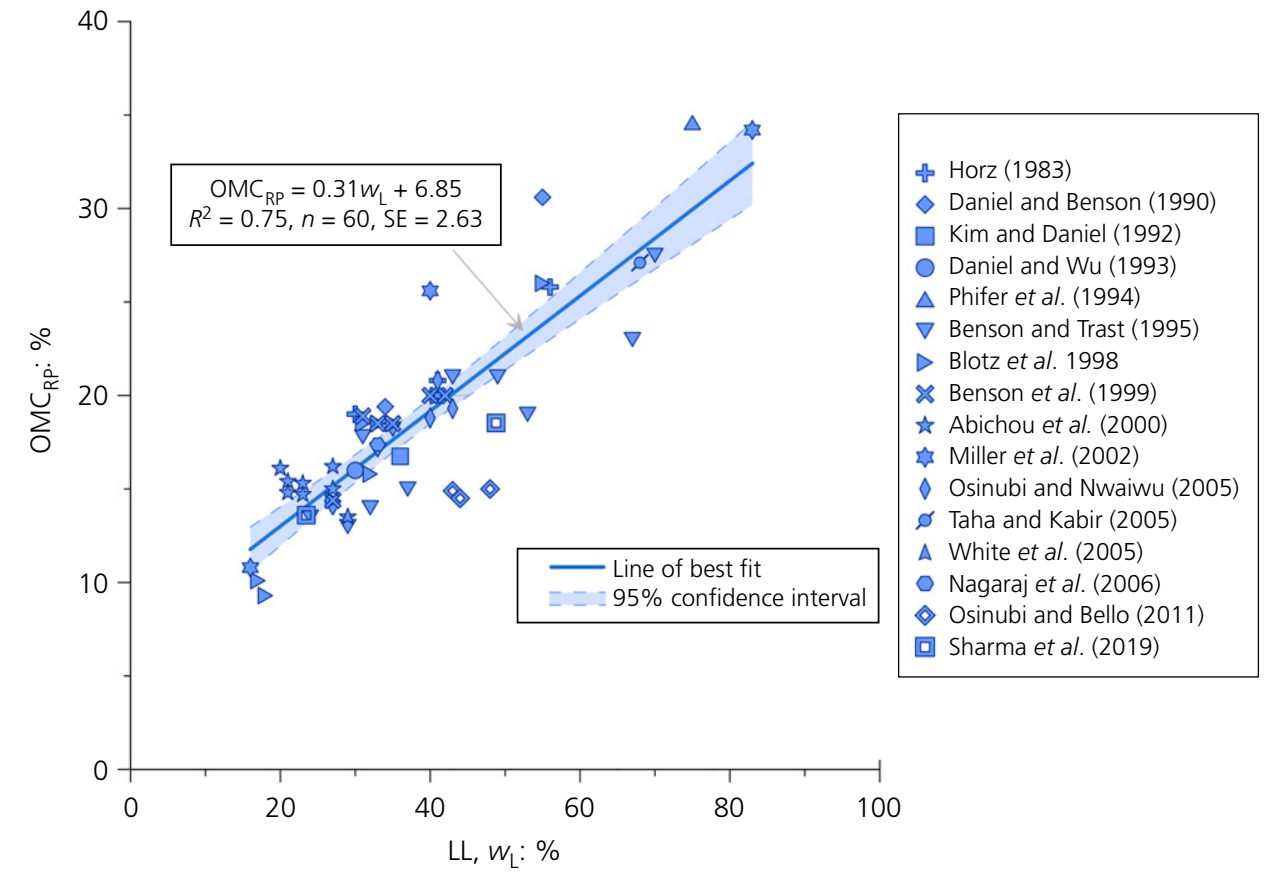

Figure 5. Relationship between $\mathrm{OMC}$ from reduced Proctor $\left(\mathrm{OMC} C_{\mathrm{RP}}\right)$ and $\mathrm{LL}$

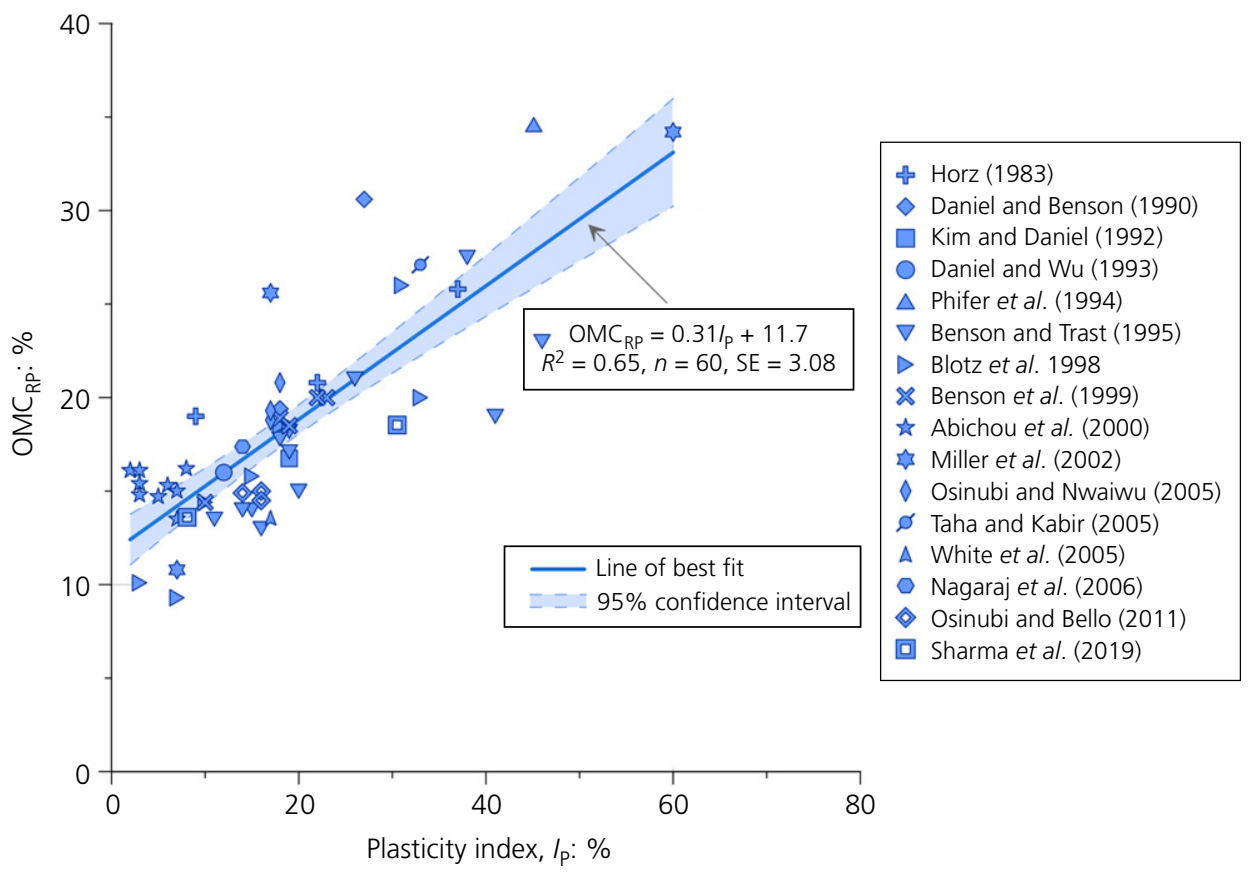

Figure 6. Relationship between $\mathrm{OMC}$ from reduced Proctor $\left(\mathrm{OMC}_{\mathrm{RP}}\right)$ and plasticity index

OMC with LL and higher $R^{2}$ values than the correlations for OMC with PL. However, plasticity index involves the determination of both LL and PL, which is more time consuming than just determining LL or PL alone. LL may thus be a more suitable parameter to estimate OMC for reduced Proctor test rather than PL or plasticity index. 


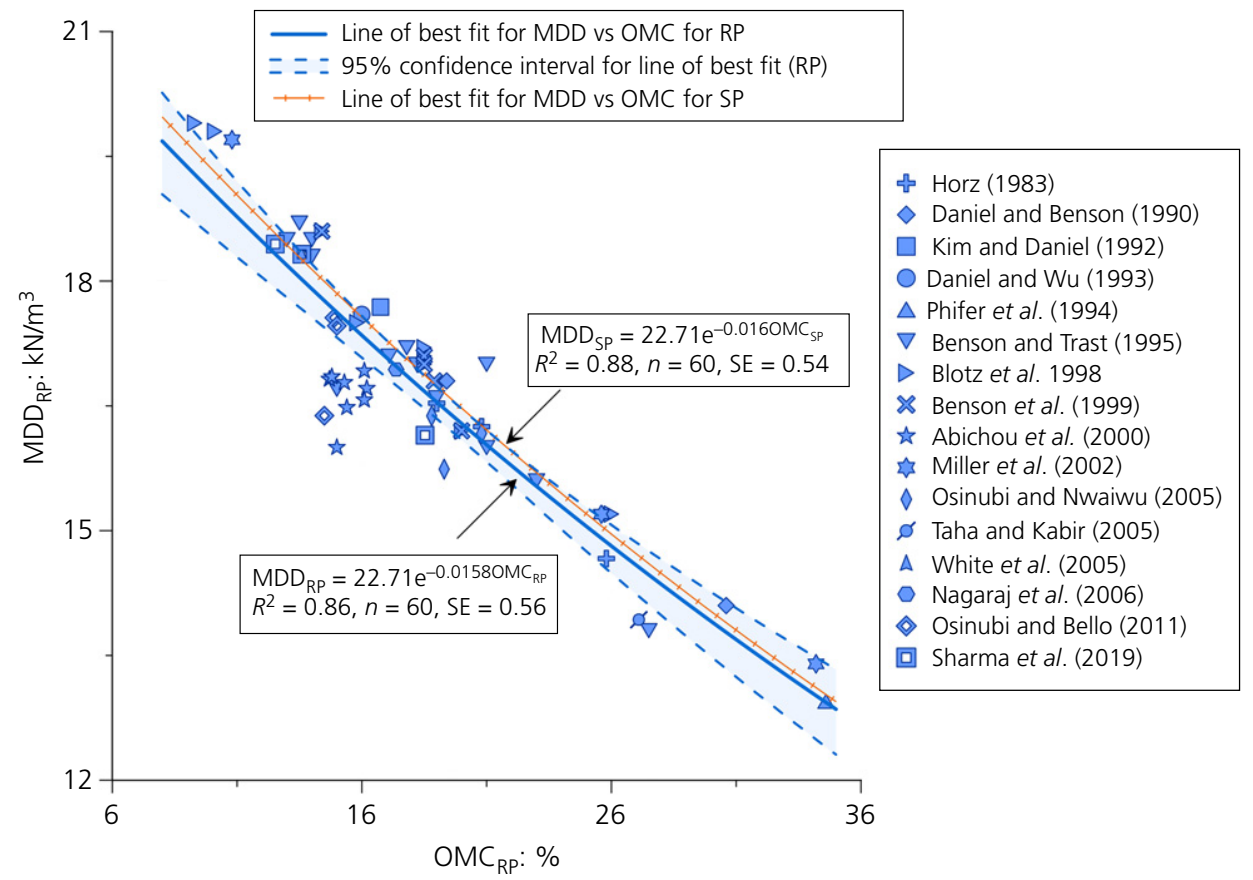

Figure 7. Relationship between maximum dry unit weight from reduced Proctor test $\left(\mathrm{MDD}_{\mathrm{RP}}\right)$ and $\mathrm{OMC}$ from reduced Proctor test $\left(\mathrm{OMC} \mathrm{RP}_{\mathrm{R}}\right)$

Table 2. Summary of the correlations developed in this study

\begin{tabular}{|c|c|c|c|c|}
\hline & Correlation & Number of data points, $n$ & $R^{2}$ & Standard error, SE \\
\hline Equation 1 & $\mathrm{MDD}_{\mathrm{RP}}=0.98 \mathrm{MDD}_{\mathrm{SP}}-0.31$ & 61 & 0.94 & 0.38 \\
\hline Equation 2 & $\mathrm{MDD}_{\mathrm{MP}}=0.85 \mathrm{MDD}_{\mathrm{SP}}+4.05$ & 58 & 0.90 & 0.42 \\
\hline Equation 3 & $\mathrm{MDD}_{\mathrm{MP}}=0.86 \mathrm{MDD}_{\mathrm{RP}}+4.54$ & 58 & 0.90 & 0.43 \\
\hline Equation 4 & $\mathrm{OMC}_{\mathrm{RP}}=1.02 \mathrm{OM} C_{S P}+1.41$ & 61 & 0.94 & 1.29 \\
\hline Equation 5 & $O M C_{M P}=0.720 M C_{S P}+1.02$ & 58 & 0.88 & 1.35 \\
\hline Equation 6 & $\mathrm{OMC}_{M P}=0.670 M C_{R P}+0.55$ & 58 & 0.84 & 1.57 \\
\hline Equation 7 & $\mathrm{OMC}_{\mathrm{RP}}=0.31 w_{\mathrm{L}}+6.85$ & 60 & 0.75 & 2.63 \\
\hline Equation 8 & $\mathrm{OMC}_{\mathrm{SP}}=0.3 w_{\mathrm{L}}+5.48$ & 60 & 0.77 & 2.40 \\
\hline Equation 9 & $\mathrm{OMC}_{\mathrm{RP}}=0.49 w_{P}+9.21$ & 60 & 0.30 & 4.41 \\
\hline Equation 10 & $\mathrm{OMC}_{\mathrm{SP}}=0.49 w_{\mathrm{P}}+7.31$ & 60 & 0.33 & 4.07 \\
\hline Equation 11 & $\mathrm{OMC}_{\mathrm{RP}}=0.36 / \mathrm{P}+11.7$ & 60 & 0.65 & 3.08 \\
\hline Equation 12 & $\mathrm{OMC}_{S P}=0.34 / \mathrm{P}+10.25$ & 60 & 0.65 & 2.95 \\
\hline Equation 13 & $M D_{R P}=22.33 e^{-0.01580 M C}{ }_{R P}$ & 60 & 0.86 & 0.56 \\
\hline Equation 14 & $M_{S P}=22.71 e^{-0.0160 M C}{ }_{S P}$ & 60 & 0.88 & 0.54 \\
\hline
\end{tabular}

Figure 7 shows the relationship between the MDD and OMC obtained for reduced Proctor test. The data were fitted with an exponential curve given by the equation

13. $\mathrm{MDD}_{\mathrm{RP}}=22.33 \mathrm{e}^{-0.01580 \mathrm{MC}_{\mathrm{RP}}}$

with a good coefficient of determination $\left(R^{2}=0.86\right)$. Similarly, the relationship between the MDD and OMC obtained for standard Proctor test (shown as the dashed line in Figure 7) is given by

14. $\mathrm{MDD}_{\mathrm{SP}}=22.71 \mathrm{e}^{-0.016 \mathrm{OMC}}$ again with a good coefficient of determination $\left(R^{2}=0.88\right)$.

It can be seen from Figure 7 and Equations 13 and 14 that the relation between MDD and OMC for both standard Proctor and reduced Proctor is almost the same.

All the correlations developed in this study are summarised in Table 2 .

\section{Conclusions}

Data collected from the literature on three compaction tests (reduced Proctor, standard Proctor and modified Proctor) and index properties (LL and PL) for 61 soils were analysed to 
validate the use of the reduced Proctor test as a replacement for the standard Proctor test. In view of the requirement of testing large quantities of soil for the construction of earthen embankments, earth dams and so on, simplified compaction tests are desirable. From this viewpoint, the reduced Proctor test requires much less time and compaction effort. Considering the benefits of the reduced Proctor test - that is, a $40 \%$ reduction in compaction energy compared with the standard Proctor test, no modifications to the standard Proctor compaction apparatus (unlike other small compaction tests) and the same soil particle size requirements and sample preparation procedure as those of the standard Proctor test - the reduced Proctor test can be used instead of the standard Proctor test. The OMC obtained from both the reduced Proctor test and the standard Proctor test was found to correlate well with liquid limit.

\section{REFERENCES}

Abichou T, Benson CH and Edil TB (2000) Foundry green sands as hydraulic barriers: laboratory study. Journal of Geotechnical and Geoenvironmental Engineering 126(12): 1174-1183, https://doi.org/10.1061/(ASCE)1090-0241(2000)126:12(1174).

Al-Khafaji AN (1993) Estimation of soil compaction parameters by means of Atterberg limits. Quarterly Journal of Engineering Geology and Hydrogeology 26(4): 359-368, https://doi.org/ 10.1144/GSL.QJEGH.1993.026.004.10.

ASTM (2012) D 698-12: Standard test methods for laboratory compaction characteristics of soil using standard effort $\left(12,400 \mathrm{ft}-\mathrm{lbf} / \mathrm{ft}^{3}\left(600 \mathrm{kN}-\mathrm{m} / \mathrm{m}^{3}\right)\right)$. ASTM International, West Conshohocken, PA, USA.

Basheer IA (2001) Empirical modeling of the compaction curve of cohesive soils. Canadian Geotechnical Journal 38(1): 29-45, https://doi.org/10.1139/t00-068.

Benson CH and Trast JM (1995) Hydraulic conductivity of thirteen compacted clays. Clays and Clay Minerals 43(6): 669-681, https://doi.org/10.1346/CCMN.1995.0430603.

Benson CH, Daniel DE and Boutwell GP (1999) Field performance of compacted clay liners. Journal of Geotechnical and Geoenvironmental Engineering 125(5): 390-403, https://doi.org/ 10.1061/(ASCE)1090-0241(1999)125:5(390).

BIS (Bureau of Indian Standards) (1980) IS 2720-7: Methods of test for soils, Part 7: Determination of water content-dry density relation using light compaction. BIS, New Delhi, India.

Blotz LR, Benson CH and Boutwell GP (1998) Estimating optimum water content and maximum dry unit weight for compacted clays. Journal of Geotechnical and Geoenvironmental Engineering 124(9): 907-912, https://doi.org/10.1061/(ASCE)1090-0241(1998)124:9(907).

BSI (1990) BS 1377-4: Methods of test for soils for civil engineering purposes - Part 4: Compaction-related tests. BSI, London, UK

Daniel DE and Benson CH (1990) Water content-density criteria for compacted soil liners. Journal of Geotechnical Engineering 116(12): 1811-1830, https://doi.org/10.1061/(ASCE)0733-9410 (1990)116:12(1811)

Daniel DE and Wu YK (1993) Compacted clay liners and covers for arid sites. Journal of Geotechnical Engineering 119(2): 223-237, https://doi.org/10.1061/(ASCE)0733-9410(1993)119:2(223).

Gunaydin O (2009) Estimation of soil compaction parameters by using statistical analyses and artificial neural networks. Environmental Geology 57(1): 203, https://doi.org/10.1007/s00254-008-1300-6.

Gurtug $Y$ and Sridharan A (2004) Compaction behaviour and prediction of its characteristics of fine grained soils with particular reference to compaction energy. Soils and Foundations 44(5): 27-36, https://doi.org/10.3208/sandf.44.5_27.

Horpibulsuk S, Katkan W and Naramitkornburee A (2009) Modified Ohio's curves: a rapid estimation of compaction curves for coarse- and fine-grained soils. Geotechnical Testing Journal 32(1): 64-75, https://doi.org/10.1520/GTJ101659.

Horz RC (1983) Evaluation of Revised Manual Compaction Rammers and Laboratory Compaction Procedures. U.S. Army Engineer Waterways Experiment Station, Vicksburg, MS, USA, Miscellaneous Paper GL-83-20.

Isik F and Ozden G (2013) Estimating compaction parameters of fine-and coarse-grained soils by means of artificial neural networks. Environmental Earth Sciences 69(7): 2287-2297, https://doi.org/10.1007/s12665-012-2057-5.

Joslin JG (1959) Ohio's typical moisture-density curves. In Symposium on Application of Soil Testing in Highway Design and Construction (STP239). ASTM International, West Conshohocken, PA, USA, pp. 111-118, https://doi.org/10.1520/STP39322S.

Kim WH and Daniel DE (1992) Effects of freezing on hydraulic conductivity of compacted clay. Journal of Geotechnical Engineering 118(7): 1083-1097, https://doi.org/10.1061/(ASCE) 0733-9410(1992)118:7(1083).

Miller CJ, Yesiller N, Yaldo K and Merayyan S (2002) Impact of soil type and compaction conditions on soil water characteristic. Journal of Geotechnical and Geoenvironmental Engineering 128(9): 733-742, https://doi.org/10.1061/(ASCE)1090-0241 (2002)128:9(733).

Nagaraj TS, Lutenegger AJ, Pandian NS and Manoj M (2006) Rapid estimation of compaction parameters for field control. Geotechnical Testing Journal 29(6): 497-506, https://doi.org/10.1520/GTJ100009.

Nagaraj HB, Reesha B, Sravan MV and Suresh MR (2015) Correlation of compaction characteristics of natural soils with modified plastic limit. Transportation Geotechnics 2: 65-77, https://doi.org/ 10.1016/j.trgeo.2014.09.002.

Najjar YM, Basheer IA and Naouss WA (1996) On the identification of compaction characteristics by neuronets. Computers and Geotechnics 18(3): 167-187, https://doi.org/10.1016/0266-352X(95) 00030-E.

Osinubi KJ and Bello AA (2011) Soil-water characteristics curves for reddish brown tropical soil. Electronic Journal of Geotechnical Engineering 16: 1-25.

Osinubi KJ and Nwaiwu CM (2005) Hydraulic conductivity of compacted lateritic soil. Journal of Geotechnical and Geoenvironmental Engineering 131(8): 1034-1041, https://doi.org/ 10.1061/(ASCE)1090-0241(2005)131:8(1034).

Phifer M, Drumm E and Wilson G (1994) Effects of post compaction water content variation on saturated conductivity. In STP1142 Hydraulic Conductivity and Waste Contaminant Transport in Soil (STP 1142) (Daniel D and Trautwein S (eds)).

ASTM International, West Conshohocken, PA, USA, pp. 318-334, https://doi.org/10.1520/STP23895S.

Ramiah BK, Viswanath V and Krishnamurthy HV (1970) Interrelationship of compaction and index properties. Proceedings of the 2nd South East Asian Conference on Soil Engineering, Singapore, pp. $577-587$.

Sharma B, Gogoi B and Sridharan A (2019) Static compaction characteristics of coarse and fine grained soils. In Solving Pavement and Construction Materials Problems with Innovative and Cutting-Edge Technologies (Hossain Z, Zhang $\mathrm{J}$ and Chen $\mathrm{C}$ (eds)). Springer Nature, Cham, Switzerland, pp. 45-57, https://doi.org/10.1007/978-3-319-95792-0_4.

Sivrikaya O, Togrol E and Kayadelen C (2008) Estimating compaction behavior of fine-grained soils based on compaction energy. Canadian Geotechnical Journal 45(6): 877-887, https://doi.org/ 10.1139/T08-022. 
Sridharan A and Nagaraj HB (2005) Plastic limit and compaction characteristics of fine-grained soils. Proceedings of the Institution of Civil Engineers - Ground Improvement 9(1): 17-22, https://doi.org/10.1680/grim.2005.9.1.17.

Taha MR and Kabir MH (2005) Tropical residual soil as compacted soil liners. Environmental Geology 47(3): 375-381, https://doi.org/ $10.1007 / \mathrm{s} 00254-004-1160-7$
US ACE (US Army Corps of Engineers) (1970) Laboratory Soils Testing. Department of the Army, Office of the Chief of Engineers, Washington, DC, USA, Engineer Manual EM-1110-2-1906. White DJ, Jaselskis EJ, Schaefer VR and Cackler ET (2005) Real-time compaction monitoring in cohesive soils from machine response. Transportation Research Record 1936: 172-180, https://doi.org/ $10.1177 \% 2 \mathrm{~F} 0361198105193600120$.
To discuss this paper, please email up to 500 words to the editor at journals@ice.org.uk. Your contribution will be forwarded to the author(s) for a reply and, if considered appropriate by the editorial board, it will be published as discussion in a future issue of the journal.

Proceedings journals rely entirely on contributions from the civil engineering profession (and allied disciplines). Information about how to submit your paper online is available at www.icevirtuallibrary.com/page/authors, where you will also find detailed author guidelines. 